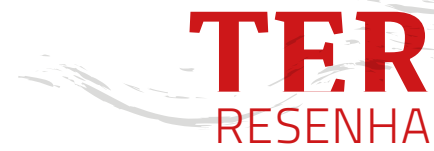

\title{
SOMA E SUB-TRAÇÃO: TERRITORIALIDADES E RECEPÇÃO TEATRAL
}

Edélcio Mostaço. 2015. Soma e sub-tração: territorialidades e recepção teatral. São Paulo: Edusp.

\section{DIEGO GONÇALES}

ORCID

Fundação Escola de Sociologia e Política de São Paulo, São

\section{RUAN FELIPE DE AZEVEDO}
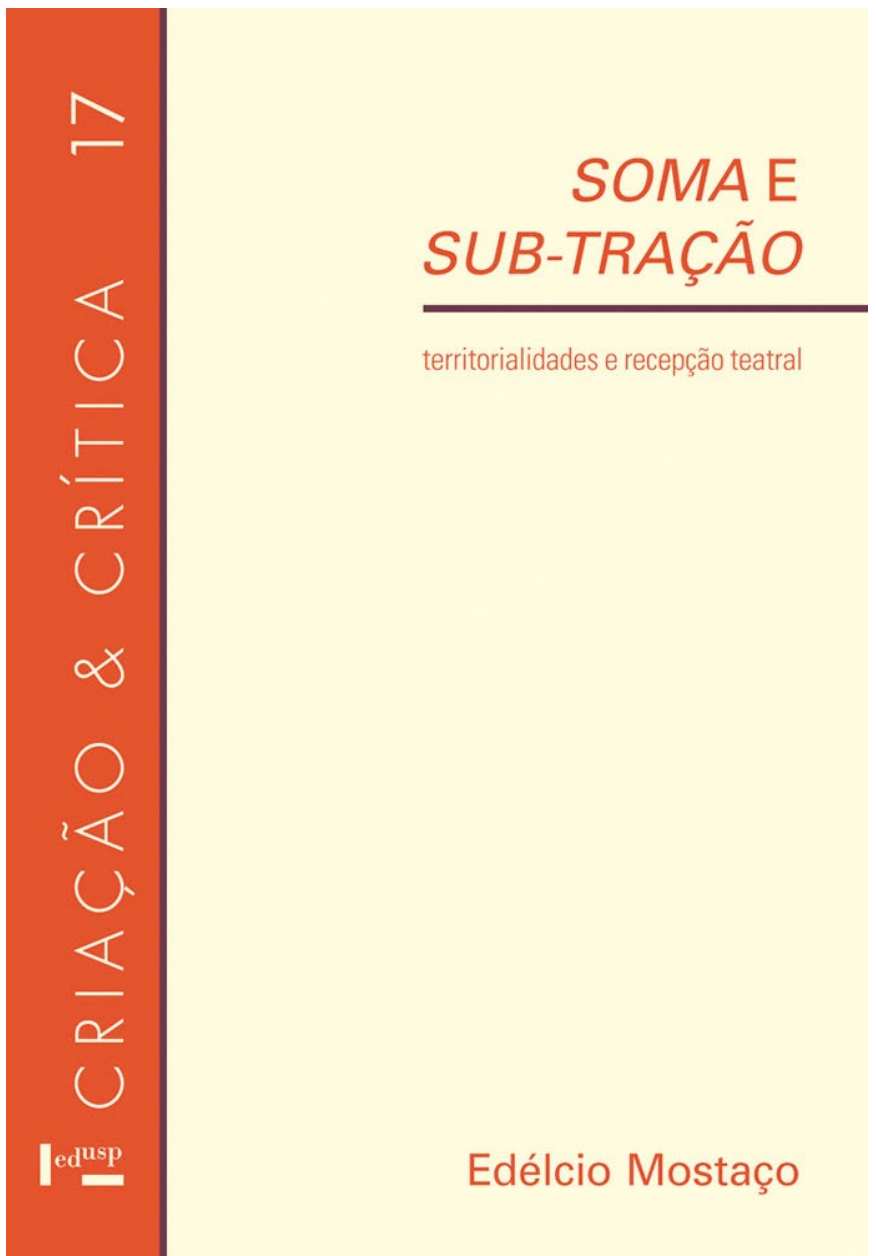

territorialidades e recepção teatral

Edélcio Mostaço 


\section{SOMA E SUBTRAÇÃO}

No livro Soma e sub-tração: territorialidades e recepção teatral, Edélcio Mostaço (2015) constrói um delicioso panorama da dramaturgia brasileira contemporânea, partindo de 1950 e chegando até 2006, elencando as principais montagens e grupos de teatro que com potência e ousadia marcaram a cena teatral no país.

o texto reúne escritos, análises e reflexões do autor em torno não somente da história do teatro, mas sobretudo da construção social e cultural das linguagens e estéticas da arte teatral, percorrendo seus realizadores, como encenadores, diretores, dramaturgos, críticos, grupos de teatro e público. Edélcio chama atenção para a produção das metrópoles e seus festivais sem se esquecer dos interiores e das produções de menos visibilidade, que também possuem grande fôlego e vigor cênico.

O livro está dividido em duas partes. Na primeira, o autor se debruça sobre os problemas levantados pela chegada da teoria da recepção, surgida na Alemanha e impulsionada pelas obras de Hans Robert Jauss (1978) e Wolfgang Iser (1996) em meados dos anos 1960. A teoria da recepção está baseada em um ponto de virada que tem como objetivo deixar de privilegiar o autor e seu universo, a fim de voltar a atenção para a obra, o leitor e o fundo social circundante que a compõe. A estética da recepção privilegia o registro da experiência e do fazer, uma construção onde se valoriza a relação com o leitor/receptor.

Essa ênfase se justifica pelo extenso debate que se faz sobre como a obra de arte, especialmente a teatral, se propaga entre o falso e o verdadeiro, o ilusório e o concreto. Uma decodificação oscilante, uma síntese que opera muito mais por um regime de disjunção e produção de diferenças que pela proposição de sínteses universalizantes e planificadoras de mundo - ou ao menos se espera que o teatro trilhe esse caminho.

O conceito de dobra, mobilizado por Deleuze (2000) para argumentar sobre a obra de arte, é recuperado no texto e nos auxilia a pensar os processos pelos quais a noção de pessoa no Ocidente escapa de sua fantasia unitária e indivisível e extrapola para fora da pele, estabelece relações de afeto, potência e implicações com o mundo exterior, colocando em perspectiva essa interação entre o fora e o dentro. "É uma cadeia formada entre conexões humanas, artefatos técnicos, dispositivos de ação e pensamento" (Ibid., 64).

Na física, "tração" é a força aplicada sobre um corpo em direção perpendicular, num sentido que possibilite provocar a sua ruptura. Soma e Sub-tração, ato de somar, subtrair e tracionar - revela os contextos em que algumas obras teatrais foram criadas ou transformadas ao longo 
de um período histórico da sociedade brasileira após a década de 1950, marcada por avanços e retrocessos, passando pelas linguagens e estéticas artísticas que contribuíram para o teatro se perpetuar sendo aquilo que sabemos: uma força que acompanha, tensiona ou mesmo acelera as transformações de uma sociedade e daquilo que dela deriva, ao mesmo tempo que a alimenta, assim como à sua cultura.

Ao narrar o percurso da "teoria da recepção", o autor inicia a sua análise pelos anos 1950, resgatando o contexto histórico-social de uma sociedade que, por um lado, avançava artisticamente, concomitante ao crescimento populacional e, por outro, se transformava rapidamente, mas em 1964 sofre o brutal golpe militar que levaria o país ao encerramento do regime democrático. A chegada da teoria da recepção no Brasil é tardia, em meados dos anos 1980, especialmente a partir da coletânea de Luiz Costa Lima (1979).

Na segunda parte do livro, denominada "Escritos descolados", Edélcio Mostaço vai direto ao ponto e, de forma cirúrgica, analisa cada obra dos principais autores e suas encenações de modo abrangente e perspicaz.

Em "arte, ciência e teatro: no rumo de uma epistemologia da pesquisa", penúltimo tema da primeira parte do livro, Edélcio Mostaço inicia o texto evocando uma citação de Marcel Mauss: "Não é a prece ou o dom que importa entender, o que conta é o melanésio de tal ou tal ilha. Contra o teórico, o observador deve ter sempre a última palavra; e contra o observador, o indígena" (apud Mostaço 2015, 85), ressaltando a ênfase que a teoria teatral tem dado para o campo da experiência e da ação.

Nas ciências das humanidades e sua epistemologia, a interdisciplinaridade e transdisciplinaridade são conceitos capazes de compreender o pensamento analítico e reflexivo como um complexo híbrido de entrecruzamentos de saberes distintos. Arte e ciência são duas grandes áreas do conhecimento aparentemente separadas, contudo essas áreas se fundem sobretudo em seus aspectos cognitivos, recuperando assim certa relação de pensamento que foi perdida ou ocultada na metafísica ocidental. Povos de antigas civilizações guiadas pelo pensamento mítico-religioso não desassociavam o fazer artístico do fazer científico, tampouco do fazer filosófico. Esse tripé se amparava na prática de observar, refletir, interpretar e experienciar o mundo de maneira intensificada e flexível, sem com isso estabelecer uma zona fronteiriça entre um universo e outro, uma vez que arte e ciência pertenciam ao mesmo elemento experimental: a magia - experiências e práticas que atravessam o tempo e espaço cronológico para um tempo/espaço cósmico onde os saberes vão ampliando a perspectiva do olhar de quem pratica e observa a vida social e, assim, vai tecendo relações que embaralham o que nós (ocidentais) definimos por natural e sobrenatural. 
O teatro, em sua complexidade, configura uma forma de experiência que se aproxima dos saberes científicos, sociológicos e antropológicos (e vice-versa) na medida em que cria e desperta experimentos cênicos capazes de analisar, tensionar ou mesmo transgredir os valores de uma sociedade. Com uma temática que reúne "Arte, ciência e teatro", Mostaço (Ibid., 90) mira o seu olhar na aproximação desses saberes logo de início, revelando que "ao tomarmos os conceitos de arte e ciência em seus grandes lineamentos históricos, observamos que entre elas não vige uma oposição, mas somente uma acentuada diferença de enfoque", sobressaltando, ainda, que tanto arte como ciência derivam de uma mesma matriz: a teoria do conhecimento.

Para o pensamento positivista, a ideia central de ciência estava relacionada à ideia de "absoluto" e de "verdade", mas com o relativismo cultural, e sobretudo com o avanço dos estudos antropológicos, podemos desconfiar que a noção de natureza e cultura seja um problema epistemológico elaborado por nós, e não um problema universal que muda a depender das diferentes perspectivas de determinadas sociedades. Isso altera a ideia de ciência como "absoluta e verdadeira" para "relativa, condicional, local e passiva de mudanças, transformações e interpretações" (Ibid., 98), retomando e revelando a importância dos pensamentos mítico e onírico, oriundos de outras formas de existir no mundo, construídos e/ou herdados pelos povos não ocidentais como produção de saberes, de forma que o modus operandi de fabricar o "pensamento científico" e o "pensamento artístico" teme suas práticas imbricadas.

A complexidade da prática teatral não se construiu de maneira desassociada do meio, seja ele social, cultural e político ou da pluralidade e multiplicidade das sociedades. A arte da imitação é uma das principais fontes de energia para a construção da identidade e sobretudo para a construção do pensamento social e seus arquétipos. Todavia, as artes expressivas do corpo formaram caleidoscópios para observar a realidade, podendo servir de incubadora social para novas experiências no modo de construir "pessoas" e relações humanas. É um organismo social constituído de interioridade e alteridade. Nas palavras do autor, "a arte é instituída socialmente, não é um produto natural ou simplesmente realizado por um indivíduo isolado. É o público - e, naturalmente, todas as instâncias que ele representa" (Ibid., 103).

Mostaço faz um breve panorama social e cultural do teatro mundial, mas mantém o foco no teatro brasileiro, remontando, através da soma de textos/fragmentos, a construção das diversas linguagens do "drama" e suas superações por meio das releituras de autores póstumos, como os exemplos da influência aristotélica e pós-aristotélica em algumas passagens descritas ao longo da obra. E isso sem ignorar a figura de grande 
destaque do jogo teatral ou, na verdade, aquela que pode ser a razão de tudo: o espectador, já que, como o próprio autor exprime, não há teatro sem espectador.

Isso conduz o autor a analisar e compreender a construção da linguagem teatral e de suas técnicas sem ignorar o público como ser ativo. É possível destacar que nesse processo interativo entre artista e público, palco e plateia, nem sempre o texto é o condutor da narrativa dramática, mas o corpo, seus lugares e seus "não lugares" como abrigos do paradigma da liberdade e da construção de novas linguagens e estéticas, transitando pelos polos "eu mesmo - no-próprio-corpo-neste-lugar - [e] o outro - no-corpo-dele-no-seu-lugar" (Ibid., 110), criando variáveis alternativas e caminhos infindáveis da arte teatral.

Edélcio também recupera as peças trágicas de uma Grécia, talvez desprezada atualmente, onde o ritual é energia vital para a vida e as relações humanas. Com o tema "Ésquilo, a hematopoiese", que inaugura a segunda parte do livro, somos direcionados ao elemento trágico do teatro como o templo consagrado ao corpo e suas expansões, para além do que é apenas físico ou psicológico - a origem do ritual de religar os corpos e seus símbolos -, tragando-nos ao humano demasiadamente humano. 0 autor narra algumas obras recuperando a tragédia grega pelo fluxo poético sanguíneo, identificando nos textos dos autores clássicos da tragédia o derramamento de sangue contido nas narrativas como uma forma de sacrifício em oferenda ao humano, ou mesmo ao não humano, e suas relações. Com isso demonstra que, na tragédia, "quem quiser compreender o sentido da vida [...] terá de dialogar com seu sangue" (Ibid.,133).

O livro representa o movimento que o teatro desempenha até chegar à cena contemporânea, deixando marcada a importância da década de 1960 e, sobretudo, de um ator protagonista de grande importância para o cenário teatral brasileiro: o professor universitário e um dos mais importantes críticos teatrais, autor de inúmeros ensaios de interpretação da história do teatro, Décio de Almeida Prado. Uma seção do livro é dedicada a fazer-lhe menção exclusiva e honrosa: "Décio de Almeida Prado e a Cumplicidade".

As novidades das produções teatrais da década de 1960, que davam à figura do encenador mais destaque do que à figura dos autores, cada vez menos respeitados - segundo anota Mostaço -, fizeram com que Décio, um dos mais importantes críticos da época, abandonasse a crítica jornalística em 1968, dedicando-se então ao ensino universitário.

Podemos analisar que o teatro brasileiro da década de 1960, como herança cristã triunfante e estritamente textual, estava sendo superado 
pelo teatro de culto à vida, ritual, rompendo com padrões maniqueístas e moralistas. 0 texto de Mostaço nos permite refletir sobre a modernização do teatro e suas heranças brechtianas, à exemplo de "O pequeno órganon", lembrada pelo autor nas belíssimas páginas sobre "Brecht, o Órganon da Diversão" como peça que refuta o aristotelismo, "ou seja, o ilusionismo cênico criado desde o renascimento, aquela massa ideológica prenhe de convenções caducas e tornada conformista, calcada sobre padrões de pensamento acumulados desde a patrística medieval e largamente disseminados nos colégios jesuítas" (Ibid., 155). Assim também o Brasil, por volta de 1950, tornava-se um panteão que recebia as influências de Artaud, Craig, Meyerhold, Stanislavski e Beckett.

Neste contexto, Décio de Almeida Prato teve uma importância imensurável por registrar as transformações que se materializavam em grupos de teatro como o Oficina e o Teatro de Arena, além da formação de vários outros emergidos a partir daí, construindo a modernização do teatro brasileiro.

Contudo, o teatro avança, percorrendo caminhos múltiplos com a ousadia de seus executores e de seus apaixonados. No último capítulo da obra, "sobre a recepção de espetáculos", Mostaço faz um grand finale expressando a importância que tem o crítico teatral em seu ofício e, por essa razão, a importância do reencantamento pela crítica teatral, de modo que ela não deve estar fadada somente a um simples comentário opinativo embutido em um espaço de jornal, mas atue efetivamente na produção de paixões pelo teatro ou por uma peça teatral específica - a mesma paixão que serve de matéria prima para as artes cênicas.

Costumo recomendar a alunos de crítica que assistam aos espetáculos com um olho no palco e outro na plateia. Com o objetivo de flagrar, desse modo, os efeitos da obra, tentativa de construir uma síntese entre seu preparo anterior, arduamente construído com estudos, e a reação viva de alguém que não ele próprio (Ibid., 160)

\section{REFERÊNCIAS BIBLIOGRÁFICAS}

Deleuze, Gilles. 2000. A dobra: Leibniz e o barroco. São Paulo: Papirus.

Iser, Wolfgang. 1996. O ato da leitura: uma teoria do efeito estético: vol. 1. São Paulo: Editora 34.

Jauss, Hans Robert. 1978. Petite apologie de l'expérience esthétique. In Pour une esthétique de la réception, Hans Robert Jauss, 50-89. Paris: Gallimard.

Lima, Luiz Costa. 1979. A literatura e o leitor: textos de estética da recepção. Rio de Janeiro: Paz e Terra.

Mostaço, Edélcio. 2015. Soma e sub-tração: territorialidades e recepção teatral. São Paulo: Edusp. 
DIEGO GONÇALES é professor de sociologia na rede pública estadual de São Paulo, com trabalhos publicados na área de educação e teatro. Sociólogo formado na Fundação Escola de Sociologia e Política de São Paulo, é pós-graduado em Estudos brasileiros: sociedade, educação e cultura, e formado em teatro na Pontifícia Universidade Católica de São Paulo (PUC-SP). É fundador e diretor da Cia. Bará, grupo teatral que há mais de dez anos desenvolve montagens, oficinas e estudos de teatro. Seus últimos trabalhos somam a teatralização dos filmes de Glauber Rocha: Deus e o Diabo na Terra do Sol, A idade da Terra e Terra em transe, completando o ciclo da "Trilogia da Terra". E-mail: diemargon@hotmail.com

RUAN FELIPE DE AZEVEDO é professor de sociologia na rede pública estadual de São Paulo e no Sesi Osasco. Mantém pesquisas em antropologia e coordena o grupo de teatro Cia. Bará. É doutorando no Programa de Pós Graduação de Antropologia da Universidade de São Paulo (USP). Nos últimos cinco anos tem se dedicado a pesquisar a construção dos corpos no teatro com ênfase nos referenciais da antropologia, com trabalhos publicado sobre o Teat(r)o Oficina e a Cia. Bará. E-mail: ruan.azevedo@usp.br

Contribuição de autoria. Diego Gonçales e Ruan Felipe de Azevedo: concepção, coleta de dados e análise de dados, elaboração do manuscrito, redação, discussão de resultados.

Licença de uso. Este artigo está licenciado sob a Licença Creative Commons CC-BY. Com essa licença você pode compartilhar, adaptar, criar para qualquer fim, desde que atribua a autoria da obra. 